\title{
The conception of humanism and its significance for nursing and the profession of a nurse
}

\section{Idea humanizmu i jej znaczenie dla pielęgniarstwa i pielęgnowania}

\author{
Grażyna Kowalik \\ Department of Nursing Skills and Labour, Institute of Nursing and Midwifery, Faculty of Health Sciences, Jan Kochanowski University, \\ Kielce, Poland \\ Head of the Department: Prof. Bogdan Chazan MD, PhD
}

Key words: nursing, humanism, care, care models.

Słowa kluczowe: pielęgniarstwo, humanizm, troska, modele opieki.

\begin{abstract}
In a few last decades there has been a change in the way the role of nursing is regarded. Education of nurses is now a part of university courses, which undoubtedly means higher expectations concerning this profession. Enabling professional nurses to perform their duties well requires more than just expertise, skills, and competences; what is necessary is deep emotional engagement with their work, which is reflected by their adequate, highly humanistic response to the individual needs of a particular patient. Many theoreticians of nursing point out in their models and theories the importance of humanistic aspects in terms of professional activities performed by nurses. The aim of this paper is to attempt to review the existing theories concerning nursing, focusing on the values of humanism, and to emphasise their significance for nursing practice.
\end{abstract}

\section{Streszczenie}

W ciągu kilku ostatnich dziesięcioleci nastąpiła zmiana w rozumieniu roli pielęgniarstwa. Edukacja pielęgniarska odbywa się na uniwersytetach, co niewątpliwie wiąże się z większymi wymaganiami wobec zawodu pielęgniarskiego. Dobre funkcjonowanie zawodowe osoby profesjonalnie wykonującej zawód pielęgniarki wymaga nie tylko fachowej wiedzy, umiejętności i kompetencji, lecz także głębokiego, emocjonalnego zaangażowania w pracę, mającego swoje odzwierciedlenie w adekwatnym i jednocześnie wysoko humanistycznym odpowiadaniu na indywidualne potrzeby konkretnego pacjenta. Wielu teoretyków pielęgniarstwa w swoich modelach i teoriach wskazuje na humanistyczne zasady w odniesieniu do działań zawodowych pielęgniarek. Celem pracy jest próba przeglądu teorii pielęgniarstwa, skoncentrowanych wokół wartości humanizmu oraz podkreślenie ich znaczenia dla praktyki pielęgniarskiej.

\section{Introduction}

Nursing has been regarded as a professional career since the $18^{\text {th }}$ century, when the first secular nurses appeared. In the middle of the $19^{\text {th }}$ century F. Nightingale, who established the first nursing school in London (1860), gave rise to modern nursing.

Nursing schools aimed at training nurses who were responsible and represented a high morale, together with an appropriate professional attitude from the very beginning. It is thus believed that the job of a nurse is based on humanistic principles and the nursing profession itself is described as a humanistic activity.

A huge impact on nursing was made by phenomenology and psychological humanism. These approaches placed the patient at the very centre of nurses' attention, making the nurse responsible for the choices made [1].

Nursing is regarded as an exceptional profession due to the unusual bond that develops between the nursed and the nursing. One may call such bond a humanistic transaction [2].

This humanistic care within nursing is highlighted by J. Watson, M. Leninger, A. Boykin and S. Schoenhofer, and K. M. Swanson in their models. R. Parse's humanistic theory of becoming a human (The Human Becoming Theory), based on philosophic works, is a kind of a practical guidebook in health care institutions in numerous countries.

Nursing practice features a humanistic approach and therefore it is advisable to study the subject of humanistic care in nursing activities. 


\section{Humanism in selected nursing models}

Humanism is a philosophical, ethical, and cultural movement originating from the Renaissance period. It was then that the importance of culture, art, and science with reference to self-actualisation of a man (Maslow's hierarchy of needs) was highlighted. The humanism of those days meant pointing out to a man his capacities, it makes us realise that we must take the consequences of our decisions.

Humanism means a collection of rules to be followed while making contact with another human altruistic, humanitarian ones, having a positive impact on people's development - humanisation.

In terms of educating and the performance of nursing staff, one should refer to both: Sartre's theory (humanistic-existential), presenting a man within becoming open, seeking his place in the world - and Heidegger's concept of human's individuality, genuine presence, care for oneself and others [1].

Nursing develops by collaborating with other disciplines, and it benefits from their achievements. Nurses are well-prepared to cooperate and act within a multi-disciplinary caring team, being aware of the consequences resulting from fulfilling their own professional roles.

Being able to evaluate a nursing job properly in terms of values requires not only social-humanistic and methodological preparation of the nurses themselves, but also realising the ideals of humanism in nursing practices.

A number of theoreticians of nursing refer in their works to humanism in nurses' training and the care they perform.

\section{Selected aspects of the Humanistic Caring Model by Jean Watson}

Taking care of ourselves and others is regarded as a decisive factor in the process of human development, in terms of staying healthy as well as of human species' survival [3].

The starting point in Watson's model of nursing care (1985) was a divergence from the former trends to regard a patient as an object rather than a subject.

The nursing job, as Watson points out, is a human science in its nature and can be referred to metaphysics, aesthetics, or other humanistic sciences [4].

Humanistic care is a multidimensional term. It can concern interpersonal relations and ought to be considered in the context of various values. Within the process of taking care of a patient, professional knowledge and skills must be involved and above all, the good will to apply them and being ready to take responsibility for the actions taken [3].

Most theories of nursing develop their assumptions starting from defining the basic terms, relevant for regarding nursing both as science and practices, which indicates the nature of the concepts and may be a starting point for further analyses. The elements usually listed are: a person (human being), health, environment and nursing (nursing metaparadigm) [5].

Watson defined a person as a unity of mind, body, and soul; a creature that is part of nature. Thus, health is a harmony of these three basic human personality dimensions, as well as living in harmony with other people and the surrounding nature. Moreover, health is associated with the degree of congruence between "the self as perceived" and "the self as experienced". A lack of harmony in this field, a subjective sense of divergence between the spheres constituting a person, could be described as an illness.

The essence of nursing is developing an interpersonal relation of caring, the goal of which is to protect, revive, and preserve humanity by helping the person to find the meaning of illness, suffering, pain, and existence; to help them gain self-consciousness, selfcontrol, so that the sense of inner harmony is restored regardless of outer circumstances. A nurse can fulfil the ideas of nursing by realising human caring.

Caring factors may help a patient to stay healthy or ensure that their death is calm. The point is to form one's own humanistic-altruistic system of values and also to sustain the patient's faith and hope, to develop sensitivity towards oneself and others. It is also truly important to understand the relations between an nurse's individual identity and his/her professional identity, which poses an attempt to become open for people and for what is important to them [3].

In human care it is essential to establish a relation with the sick and have an individual-subjective approach, to build bonds based on help and trust, as well as to accept and encourage expression of emotions, both positive and negative.

Applying a scholarly method to the decisive problem-solving process systematically must be regarded as a caring factor as well, enabling a nurse to understand the relation between the actions taken and their influence on the patient's health.

Watson also underlines the importance of health education for carrying out caring tasks - promoting interpersonal teaching and learning and providing a supporting, protecting, or correcting environment (stress prevention, ensuring comfort, privacy protection, providing security, clean and aesthetic surroundings).

Considering the patient's care, the author focuses on addressing or assisting addressing the needs of both lower and higher rank, as well as the need of selffulfilment. Getting to know the patient and taking an interest in their problems allows an understanding the sick in borderline situations (suffering, death), when anyone asks questions concerning the meaning of life. According to J. Watson, opening to the exis- 
tential dimension of one's being facilitates a nurse's professional performance [6].

The essence of Watson's theory is care and caring factors that would rather be put into nursing practice. Watson emphasises the role of humanism and a humanistic-altruistic approach in nursing, at the same time pointing out the need to maintain balance between scientific knowledge and humanistic practice.

The model of human caring is part of nursing studies curricula in the USA, it is also the core curriculum of nursing doctoral studies.

\section{Humanistic approach in a nurse's dealings in Madeleine Leiniger's Transcultural Model}

Madeleine Leiniger, in her model of transcultural nursing (1980), points out that nursing belongs to the humanistic disciplines of science and professions. The objective of a nurses' activities is to serve people all over the world. Caring plays an important role in treating and healing - there is no healing without caring.

Nurses' care can be taken only when the values, expression, or cultural role models are known to the individual, the group, the family, the community, and are used in an appropriate way by the nurse - together with other people [5].

The humanistic approach should be regarded as an intellectual and moral approach expressed in an interest in human activities, respecting people's dignity and freedom, in concern about their needs, happiness, and free development. The humanistic approach pays close attention to reasoning and is free from religious dogmas, simultaneously focusing solely on universal aspects of human life that are present in all cultures.

Apparently, such an approach can be especially helpful while establishing contact with a patient from another part of the globe.

Leininger, while working with mentally impaired children who came from different cultural backgrounds, noticed that taking care that is in accordance with cultural aspects of the patients' environment and with their philosophy of life guarantees proper understanding of their health condition in light of their attitudes, lifestyle, and beliefs $[7,8]$.

Due to her neutral views and humanistic approach while establishing first contact with the patient, the nurse appears to the patient as someone accepting his/her political and religious preferences. The cultural sphere is no longer relevant.

Following the rule of the greatest possible assimilation with the patient, in non-secular medical centres it is advisable to show the patient one's religious affiliation by making gestures and saying words that confirm that fact.

It happens occasionally, however, that the rules of transculturalism in views or neutrality are not obeyed, and the humanistic approach is not adopted. An example could be the hospital admission of a pa- tient having different views or beliefs in a non-secular institution or placing religious symbols of one's own faith despite the fact that the institution is indeed secular.

Expressing one's own faith indicators in the case of a nurse may be the reason why patients not sharing the nurse's belief could feel ignored and sense that lack of respect towards their freedom of worship. Demonstration of religious symbols by a nurse in a secular medical centre can be an obstacle for communication if the patient has strong views. As a result of this, it is likely for the sick to no longer trust the nurse or his/her caring activities [7].

Apparently, a neutral and humanistic approach that allows one to establish a patient's trust, recognising the importance of the patient's personality, and showing respect are especially useful to build a caring relationship.

\section{Care in Anne Boykin and Savina Schoenhofer's Model}

The authors of the model of care, A. Boykin and S. Schoenhofer (1993), believe that care is a way of human being, a very essential feature and expression of humanity. To be a human is to live caring for others. Care is a principal value in a nurse's private and professional life.

The basis for this model is an assumption that people need other people's care, and being a nurse means a life vocation resulting from one's own natural need to care for others. In a nurse's activities deliberate and authentic care is necessary [9].

A nurse goes to great lengths to know, understand, support, and strengthen those she takes care of.

The authors claim that it is necessary to broaden knowledge concerning care in nurses' job. The assumption that all of the people are equally careful does not mean that every human action is driven by care. The ability to express care changes and develops throughout people's lives. Understanding the significance of being considerate, of living in care, and carefully nursing others is a constant element of our lives [10].

The main postulates of the model of care are as follows:

1. People are caring because of their humanity (they possess this value since birth).

2.A person is the whole of being. Physical, spiritual, and emotional aspects mingle and constitute the whole. A holistic approach towards patients and their problems is essential in care.

3. Caring is a never-ending process in human life. Nurses take care of the healthy and the sick, from birth to death. Even a brief "How are you?" said by a nurse to a patient is an indicator of consideration for him or her. 
4. Taking care of others is a way of life rooted in personality. It is important for a nurse to behave in accordance with his/her views.

5. Participating in caring relationships makes one's personality stronger. Nursing care for other people is evidence that these people are treated with love, like family members.

6. Nursing is a profession, but also a discipline [11].

The abovementioned assumptions, once put into practice, constitute the basis for effective nursing activities, according to the authors of the model.

The main terms used in this model incude:

- Nursing - caring activities in which one shows consideration. Nursing focuses on the knowledge necessary to understand what it means to be a human.

- Health - the state of wellness.

Person is regarded as a person, as caring - and as a whole.

Co-operation and sharing one's experience is essential in nursing activities. A nurse should show consideration at every person's service.

In this model one can observe references not only to caring in nursing activities, but also to communication with the sick. A nurse shows interest in the sick and their situation not necessarily by asking the question of what he/she could do for the patient, but by investigating what is most important for the patient. A nurse dealing with ill people, by focusing on patients' problems, may redirect their attention from the very function she performs.

Nursing care is expressed by patience, understanding, and the ability to listen.

The interesting thing is the image presenting the idea of the care model. The symbol of the dance of considerate people consists of a simple circle with different people coming in and out of the ring. What is common is the fact that each person in this circle has made a resolution to be caring and considerate. All of the people in the ring undertake a task that must be done to the best of their abilities. The vision of the dancers plays an integration role. All the dancers respect one another. The dynamic, rhythmic character points to human creativity [12].

It is difficult, according to the authors of the care model, to speak of getting to know other people without offering them care and consideration, as this is how the bond between two people is shaped.

Nurses who are aware of the need for considerate care will treat each patient as an individual, paying attention to what is the most important for him or her, and they take particular care, which makes the sick satisfied with the nursing activities.

Offering support and keeping patients in good spirits are indispensable in the caring process. Nurses have to listen actively to those they take care of, to show empathy and sensitivity towards patients' problems (a nurse must do her best to enter her patient's world, teach how to take care of oneself and live at that moment).

Learning about a patient involves a personal relationship, taking into account the experience of former contact with the sick.

\section{Care theory by Kristen Swanson}

Kristen Swanson's theory is based on research and practice (1980). Kristen Swanson carried out research on miscarriages and the therapy following them, which should cover both the parents and the families who experienced the problem of miscarriage.

Swanson in her theory concerning care puts a lot of emphasis on faith in people, the need for learning about each other in the nurse-patient relationship, and of personal problems from showing interest and devoting time for each other. The author notices care in every single action taken.

Swanson's academic research covers:

- miscarriages and taking care of women,

- care in a neonatal intensive care unit,

- clinical nursing models.

The theory represents the view that both nurses and the person they take care of participate in the caring process, and by mutual support they achieve the desired goals. The objective in this theory is to draw attention to nurse's assistance. He/she provides care and thus promotes dignity and respect for the subject of her care. The author sets clear limits for caring in her deliberations, defining, describing, and exemplifying the activities. The example is explanation as enabling: providing information and explanation as well as the offer of emotional support [13].

The basic postulates of the theory are as follows:

- A human: a unique being who is a bio-psycho-social whole, which is expressed in their thoughts, emotions and actions,

- Environment: has influence on a person in any context,

- Health: health and well-being are regarded subjectively, they are associated with other values and establishing lasting bonds among people,

- Nursing: offers care and consideration for the sake of others.

The care process in Swanson's theory:

1. The concept: Keeping faith

It assumes keeping faith in one's own abilities lest unwanted incidents should pose an obstacle.

2. The concept: Knowledge

It means the attempt to understand the sense of what has happened in other people's lives, avoid formulating hypotheses, focus on taking care of a person, look for directions, engage in learning of the patient and in caring process itself.

3. The concept: Being with

It refers to respecting others' emotions, it covers the nurse's presence at the patient's side, availability, and chances to express emotions. 
4. The concept: Doing for

It emphasises that a nurse should do for others what he/she would like to be done for him/her in case she is in need.

5. The concept: Enabling

It refers to making it easier for each other (nurse patient) to go through different hardships and unexpected situations.

Swanson's theory was conceived for the sake of childbirth and puerperium care, but can be successfully applied within the whole range of nursing activity fields, including palliative care, mental disorders, and dementia. It can also be used for parent support groups and home care and treatment.

Caring is based on right interactions between a patient and clinical care team members, it is the basis for the relations of knowing and caring. This relation leads to a high level of engagement among the patient and care team members and is the foundation for caring activities.

Swanson's theory is easily applied in nursing practice, because it is clear and simple. Each process is clearly defined. A nurse provides considerate care at every stage of caring activities, helps the patient being taken care of to understand the goal of the activities, and negotiates everything that is associated with starting the activities with the sick, endlessly engaging the patient in the process of caring [14].

What especially interests Swanson is the proper care taken of women that have miscarried. In her research, the author studies the techniques of coming to terms with an early loss of pregnancy, which poses a problem for both mothers and fathers.

Swanson's practices have been incorporated into nurse training and midwife practice models throughout the world [15].

Swanson's theory reflects and fully corresponds with Watson's theory of caring. Both the authors agree that care remains the essence of nursing activities.

\section{Rosemarie Parse's Humanistic Theory of Human Becoming}

Rosemarie Parse's theory - The Human Becoming Theory, which was originally named Man-living-health (1981), belongs to the human sciences. The name was officially changed in 1992. The basis of this theory is formed by the belief that people together shape their existence in the universe in a mutual process, co-constituting an easily distinguished paradox pattern featuring uniqueness regarding both people and the universe. This theory was conceived on the basis of philosophers' works: Heidegger's, Sartre's, and of the original model by M. Rogers.

This theory is structured around three themes: meaning, rhythmicity, and transcendence.

- The meaning (sense)
A human freely makes choices in different situations, in the inter-subjective process of priorities and values.

People's reality makes sense thanks to what they have experienced.

- Rhythmicity

Unity of life covers apparently opposite ideas in rhythmic patterns, associated with the universe. Rhythmic changes are observed with regard to appearing opportunities and obstacles at every moment of people's lives.

- Transcendence

The term means going beyond "now", breaking away, creating ("forging") one's own unique path for each person, a path between ambiguities and neverending transformations. It refers to reaching beyond the limits set up by a human, which are constantly transformed.

The essence of the theory:

The Human Becoming Theory claims that:

A human is a combination of biological, psychological, sociological, and spiritual factors. A human is a unitary being staying in a continuous interaction with the surrounding environment.

Nursing Job Paradigm:

- Person

A human is a being who is more than and differs from other elements of the surrounding world.

- Environment

Everything concerning the person, including his or her experience - inextricable and complementary.

- Health

Means the process of being and becoming. It covers the synthesis of values.

- Nursing

A human science and art, which applies an abstract collection of known elements in order to serve people [16].

The assumptions of Parse's theory developed at the philosophical discourse level are as follows:

1. A human being, by co-existing with the universe, makes up a rhythmic structure.

2. A human is a free creature, which makes free choices and bears responsibility for them.

3. A human makes an inextricable unity ever co-constituting patterns of relating.

4. A human is able to transcend his possibilities multidimensionally.

5. Human becoming is an open process resulting from experiencing life.

6. Human becoming is a rhythmic process constituting the human-universe relation.

7. Human becoming is creating patterns of relating value priorities.

8. Human becoming is an intersubjective process of transcending one's abilities.

9. Human becoming is the human process of evolution. 
The Human Becoming Theory features three principles [17]

1) Structure principle

Underlines the need of individual choice. Every human wants to choose their own reality. It is obvious that many people make choices on the basis of everchanging perspectives and interpretations.

What may be helpful:

- Imaging - personal interpretation of knowledge about the world around us. It is a way to seek answers to the questions that haunt humans and to understand the meaning of events. Nurses are obliged to respect every patient, they experience problems that people deal with, observe how the sick accept their situation, how they interpret it, and if they manage in difficult situations.

- Valuing - people make their decisions regarding their own personal point of view and their perception by the community. Nurses try to know what the patients believe is important for them.

- Languaging - seeking common grounds. Languaging means how the particular person expresses his or her opinions regarding the surrounding reality, which may be reflected in the way of speaking, in closing oneself from the world around, and in this person's body language.

Nurses can face problems when interpreting the patients' words or their body language. It is the actual verbal speech that allows agreeing on the patient's current needs, the goal of which is to ensure physical and mental comfort for the sick.

2) Co-creating principle

What may be helpful:

- Revealing-concealing - the way people discover themselves, although it happens that they hide who they actually are. People get to know themselves and one another constantly throughout their lives.

This concept is useful to establish a healthy relationship between the nurse and the patient during his or her recovery.

- Enabling-limiting - this concept refers to the way in which people are forced to make decisions without any knowledge about its possible result. Frequently, making any decision is a step forward, towards something better, a positive change; it may, however, bring many limitations.

Nurses can use this concept to help patients and their family members to consider many alternative actions and reveal potential results of those difficult choices.

- Connecting-separating - is how and whether a person feels bound to stay among people, expresses the will to further pursue their goals in life.

Nurses can be involved in this concept by asking the patients about relations between people from their closest environment they find important and about their life goals that the patients intend to achieve despite their illnesses.
3) Transcendence principle

What remains essential

- Powering - is the way to enable oneself to deal with any hardship that life brings. A human must have the inner power to manage the difficulties. R. Parse describes powering as an inner process of pushing and resisting that features challenging situations in everyone's life.

It confirms the human's being against the prospect of non-being (death, loss, or rejection risk).

Nurses should be available for the patients and let them manage on their own as much as they can. Seeing that the patient faces serious difficulties, the nurse can offer him or her some help.

- Originating - one should bear in mind that every human individual is exceptional and unique, but it must be remembered that there are social rules and norms to follow, which is the basis of this concept. In caring work, nurses should adjust the changing models of health according to the multi-cultural character of their patients.

- Transforming - the concept is based on the idea that human views are subject to changes, which is the result of human experience (in personal and temporal terms for the human).

Nurses can help the patients through noticing their needs and attempts to satisfy them [17].

The human becoming theory is exceptional because is assumes a never-ending search for methods that can be widely and effectively applied and thus positively affect the multi-dimensional process of healing.

Parse's theory focuses on looking for up-to-date methods of nursing care; therefore, it abandons traditional models.

The author does not illustrate the "fixing" factors themselves, but accompanies the patient in the whole healing process, focusing on the fact that he or she is an individual being, with their own unique set of experiences.

Parse's theory is a guidebook for nursing practices in health care institutions in Canada, Finland, South Korea, Sweden, and the United States, and its research methodology is known and applied by nurses in Australia, Canada, Denmark, Finland, Greece, Italy, Japan, South Korea, Sweden, the United Kingdom, and the United States [17].

Human becoming is a nursing theory that is an alternative for both conventional bio-medical and bio-psycho-social-spiritual approaches - and for most other approaches in the nursing theory.

The Human Becoming Theory assumes that improving the quality of life from each patient's own perspective is the goal of nursing practice. According to Parse, caring schemes must take into account the emotional and psychological needs of the patient. The person in care and the nurse should establish a personal relationship resulting from sharing sadness, 
laughter, joy, and feeling empathy, and compassion. For optimal recovery, the patient needs to find balance of the body, the mind, and the spirit. Nursing should be based on continuous monitoring of the patient's experiences, preventing further complications or potential difficulties that the patient may face - by always regarding his or her mental or spiritual as well as psychological needs. A patient's education is important. The sick should be taught how to be responsible for their health and made able to satisfy their own needs.

Parse understands nursing as a humanistic approach towards the individuality of a human being, and recognises health theory as the theory of human "becoming". Parse's theory differs from the traditional care process, especially because it does not attempt to "fix" or "solve" problems. Nursing with regard to this theory is not based on a doctor or nurse's diagnosis, and it does not concern preventing disease or restoring health. It involves being together "with" patients and their families rather than doing something "for" a patient. The ability to perceive patients' perspective allows a nurse to "be with" patients and lead them towards desired health outcomes [18].

\section{Conclusions}

Nursing has its humanistic "framework". The main goal and task of a nurse has always been to offer help and care to those who are in need. Nursing is an art, a science, but above all - a service. It is one of the most significant expressions of people's humanism $[19,20]$.

It remains an important issue to recruit the best candidates for this job and to strengthen their self-esteem, competences, dignity, the will to develop and to be driven by general or professional ethics principles and humanistic values in their work with those taken care of. The essential factors will always comprise the candidates' abilities and their personal qualities such as goodness, honesty, human love.

Humanism enriches the understanding of a human and where a human belongs. A truly humanistic approach means expressing views that human dignity is invincible in each human being. A humanist is a person for whom moral values prevail material ones.

A nurse should remember that people at each stage of their development need to know joy, freedom, and the beauty of their own abilities. In caring activities there is a need to consider various needs of a human, and his or her body and spirit.

Caring as a trace of humanity is realised in contact between humans. The intimacy they experience while taking care makes nurses responsible for protecting human dignity and humaneness.

Each nurse must follow the idea of humanism, they should be compassionate, which brings people closer to each other, not only in psychological but also in ethical aspects. Sympathy is a provision for strong identification with the suffering sick individual, it is a condition, in psychological understanding, for ethical conduct [21].

From the presented theories one can assume that, while taking care of patients, compassion, devotion, and trust, as well as carrying out caring duties in accordance with one's conscience, bear a special significance.

One should also bear in mind one essential aspect - and an obligation as well - regarding the rewarding, emotional, and professional support for medical workers in their duties. This support is an indispensable condition while achieving professional goals. It also helps to accept the inevitability of passing of human life. Without this acceptance it is impossible to be fully professional in medical science. As a result, one may become dehumanised.

\section{Conflict of interest}

The authors declares no conflict of interest.

\section{References}

1. Lipiec-Wolska K. Humanizm w pielęgniarstwie. Pielęgniarstwo 2000 1996; 29: 15-6.

2. Zając M. Podmiotowe relacje z pacjentem. Humanistyczna transakcja. Mag Piel Pol 2010; 11: 14-5.

3. Watson J. Nursing. The philosophy and science of caring. University Press of Colorado 2008; 4: 17-29.

4. Watson J. Nursing. Human Science and Human Care. A Theory of Nursing. Jones and Bartlett Publishers, London 2007; 8-18.

5. Poznańska S, Płaszewska-Żywko L. Wybrane modele pielęgniarstwa. Podstawa praktyki pielęgniarskiej. Wyd. UJ, Krakow 2001.

6. Dobrowolska B, Nyklewicz W. Filozofia humanistycznej troskliwości - ludzka teoria pielęgnowania. Sztuka Pielęgnowania 2012; 4: 28-9.

7. Nyklewicz W. Komunikacyjne aspekty świątecznej wielokulturowości w pielęgnowaniu człowieka. Sztuka Pielęgnowania 2012; 4: 31-3.

8. Charońska E, Janus B, Salczyńska K. Podstawowe założenia transkulturowego modelu pielęgnowania jako wkład $\mathrm{w}$ humanizm pielęgniarstwa. Conference papers, Busko Zdrój 1998; 16-20.

9. Boykin A, Schoenhofer S. Nursing as caring: a model for transforming practice. Jones and Bartlett, Sudbury, MA 2001.

10. Boykin A. Living a caring-based program. National League for Nursing Press, New York 1994.

11. Boykin A, Schoenhofer S. Caring in nursing: analysis of extant theory. Nurs Sci Q 1990; 3: 149-55.

12. http://www.emergingrnleader.com/tag/anne-boykin/ Available at: 23 VI 2015.

13. Swanson KM. SON's Sixth Dean. Takes Helm on Aug. 1, 2009 Friday, July 31, 2009 http://carolinanursingnews. com/2009/07/31/kristen-m-swanson-sons-sixth-deantakes-helm-on-aug-1/23 Available at: VI 2015.

14. Marilyn E. Parker Nursing Theories and Nursing Practice. $2^{\text {nd }}$ ed. A. Davis Company, Philadelphia 2005. 
15. Kristen Swanson's Middle Range Theory of Caring: A Critique Lisa Armstrong NURS 900.01: Discipline of Nursing (Fall 2012) November 24, 2012. https://taskurun.files. wordpress.com/2011/10/nursing_theories_and_nursing practice_second_edition.pdf/ Available at: 23 VI 2015.

16. http://currentnursing.com/nursing_theory/Rosemary Pars_Human_Becoming_Theory.html/ Available at: 25 VI 2015

17. Basavanthappa BT. Nursing Theories. Jaypee Brothers Medical Publishers, New Delhi, India 2007.

18. Fawcett J. 21st-Century Updates - Rosemarie Rizzo Parse Scholarly Dialogue The Nurse Theorists. Nurs Sci Q 2001; 14: 126-31.

19. Dobrowolska B. Humanizacja w zawodzie pielęgniarek a etyka. Conference papers, Busko 1998; 4-7.

20. Wyrzykowska M. Humanizm w pracy pielęgniarek. Conference papers, Busko 1998; 8-11.

21. Florek K. Przybliżyć człowieka człowiekowi. Conference papers, Busko 1998.

\section{Address for correspondence:}

Grażyna Kowalik

os. Na stoku 72/19, 25-327 Kielce, Poland

Phone: +48 507186958

E-mail: grazynakowalik2@wp.pl 